\title{
Disinfection efficiency of hospital infectious disease wards with chlorine dioxide and hypochlorous acid
}

\author{
Ming-Chun Lu • Po-Lin Chen • Da-Ji Huang • Chih-Kuo Liang • \\ Ching-Shan Hsu $\cdot$ Wei-Ting Liu
}

Received: 17 August 2019/Accepted: 22 October 2020/Published online: 5 November 2020

(C) Springer Nature B.V. 2020

\begin{abstract}
The disinfection efficiencies of two chemical disinfectants, chlorine dioxide and weak acid hypochlorous water (WAHW), were examined in the soiled room and dishwashing room of a hospital infectious disease ward in Taiwan. The investigations were conducted in two seasons, namely winter and summer, in order to examine the correlation between the bioaerosol concentration and the environmental factors. In addition, a single-daily disinfection mode (SM) and a twice-daily disinfection mode (TM) were applied in this study. The results showed that the bacteria and fungi colony counts were strongly correlated with the temperature. Both disinfectants reduced the bacteria and fungi concentrations in the considered rooms. However, of the two disinfectants, the $\mathrm{ClO}_{2}$ showed a stronger disinfection effect than the WAHW. It means that when using $\mathrm{ClO}_{2}$ as the
\end{abstract}

M.-C. Lu · D.-J. Huang · C.-S. Hsu ( $\varangle)$ · W.-T. Liu Department of Environmental Resources Management, Chia-Nan University of Pharmacy and Science,

Tainan 71710, Taiwan

e-mail: hsuching627@gmail.com

P.-L. Chen

Center for Infection Control and Department of Internal Medicine, National Cheng Kung University Hospital, College of Medicine, National Cheng Kung University, Tainan 70101, Taiwan

\section{C.-K. Liang}

Department of Electrical Engineering, National Taitung Junior College, Taitung 95045, Taiwan disinfectant, the disinfection efficiency of the TM treatment mode is significantly better than that of the SM treatment mode. But, when using WAHW as the disinfectant, no significant difference is found between the disinfection efficiencies of the two methods. Overall, the results showed that the application of $\mathrm{ClO}_{2}$ twice daily provided the most effective means of satisfying the Taiwan EPA guidelines for the indoor air quality of hospital medical wards.

Keywords Disinfectant $\cdot$ Chlorine dioxide $\cdot$ Weak acid hypochlorous water $\cdot$ Ward $\cdot$ Bioaerosols

\section{Introduction}

In hospital buildings, there is a fertile breeding ground for many medical disorders, including allergies, asthma and infectious diseases (ACGIH 1999). Hospital wards are closed spaces and are therefore at a very high risk of microbial contamination. The bioaerosols containing pathogenic bacteria in the environment of hospital buildings put patients and even hospital personnel into a dangerous situation (Abreu et al. 2013). Due to the risk may happen in the hospital, there were many studies investigated the airborne bioaerosols and their impacts on the indoor air quality in hospital wards (Beggs 2003; Bhalla et al. 2004; Boyce 2007; Maclean et al. 2015; Dancer 2009). 
The total bioaerosol particles in indoor environments should be less than $1000 \mathrm{CFU} / \mathrm{m}^{3}$ according to the National Institute of Occupational Safety and Health in America and the American Conference of Governmental Industrial Health (ACGIH, and the total culturable count for bacteria cannot be higher than $500 \mathrm{CFU} / \mathrm{m}^{3}$ (NIOSH 1998; ACGIH 1989; AIHA 1996). However, Taiwan lies in a subtropical zone, and is usually warm and humid throughout the entire year. As a result, the local climate is highly conductive to the growth of bioaerosols (Hsu et al. 2012). According to the results of one long-term monitoring study, the concentration of biological contamination in Taiwan is much higher than the value of $1000 \mathrm{CFU} / \mathrm{m}^{3}$ recommended by the WHO (Hsu et al. 2015). Therefore, in Taiwan, the bacteria concentration of indoor public spaces including medical centers and hospitals should be lower than the value of $1500 \mathrm{CFU} / \mathrm{m}^{3}$, and the fungi concentration should be less than $1000 \mathrm{CFU} /$ $\mathrm{m}^{3}$ (Taiwan EPA 2012). Therefore, an effective disinfection protocols for maintaining satisfied indoor air quality (IAQ) are an issue worthy of paying attention.

Gaseous chlorine dioxide $\left(\mathrm{ClO}_{2}\right)$ is a commonly used disinfectant for reducing the impact by microbial growth (US EPA 2007). It has the ability to destroy all manner of bacteria, spores, fungi, viruses and even protozoans (Loretet al. 2005; Otaga et al. 2016). Chlorine dioxide can readily dissolve in water and at room temperature, can evaporate to spread through the environment, providing a strong disinfection effect. Chlorine dioxide molecules can spread very well including building cavities, and therefore can have an extremely thorough disinfection performance (Buttner et al. 2004; Lowe et al. 2013). Previous studies showed that weak acid hypochlorous water (WAHW) also has a good disinfection performance (Abadias et al. 2008; Koide et al. 2009; Rahman et al. 2010; Ono et al. 2012). WAHW is generated from water and dilute salt solution and its final product is water after use (Hricova et al. 2008; Møretrø et al. 2012). Therefore, WAHW has attracted significant interest recently. The efficiency of WAHW in disinfecting monoculture bacteria, namely E. coli, S. aureus, Salmonella, Vibrio, Bacillus spores, Leuconostoc sp. and virus (Cao et al. 2012; IssaZacharia et al. 2010; Quan et al. 2010; Kim et al. 2008). Furthermore, WAHW has multiple disinfection mechanisms, and is hence an ideal broad-spectrum disinfectant (Zhang et al. 2011; Chuang et al. 2013).
As described above, hospital medical wards are particularly prone to bioaerosol contamination. In Taiwan, Bacillus spp., Micrococcus spp., and Staphylococcus spp. bacteria were found in the operating theater area. Furthermore, Acinetobacter spp. was the main pathogen in the post-operative recovery room and traumatic surgery room (Tang and Wan 2013). Consequently, effective methods for disinfecting the ward and maintaining a good IAQ are essential in protecting the health of the patients, visitors and medical personnel. The requirement for effective disinfection protocols is particularly strong in the case of infectious disease wards, where the spread of infection must be strictly controlled in order to prevent the transmission of the disease to others and the occurrence of further outbreaks. Accordingly, the present study investigates the effectiveness of two disinfectants, namely gaseous $\mathrm{ClO}_{2}$ and WAHW, in optimizing the IAQ in the infectious disease ward of a teaching hospital in southern Taiwan. Two treatment modes are considered, namely single daily and twice daily. Experiments are conducted in two public rooms of the infectious disease ward, namely the soiled room and the dishwashing room. Furthermore, to examine the year-round effectiveness of the two treatment protocols, investigations are performed in both the winter season and the summer season to investigate how to improve the environmental quality with different disinfection methods by using chlorine dioxide and hypochlorous water.

\section{Material and methods}

Figure 1a presents a schematic representation of the infectious disease ward considered in the present study consisting of twenty-seven negative-pressure rooms, a nursing station, a soiled room (SR) and a dishwashing room (DR). The SR is a public open space with two normally-open doors, and is used primarily to collect and wash dirty clothes and sheets (Fig. 1b). Meanwhile, the DR is a public and open space with one normally open door, and is used to supply drinking and cleaning water, to wash the patients' dishes after eating, to provide crushed ice for body cooling, and so on (Fig. 1c).

For both rooms, air samples were collected prior to the disinfection process in order to determine the background concentration levels of bacteria and fungi. 
(a)

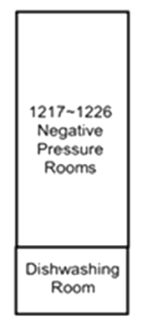

(b)

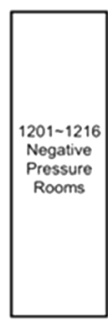

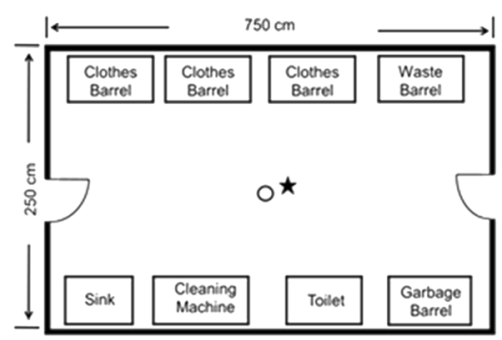

(c)

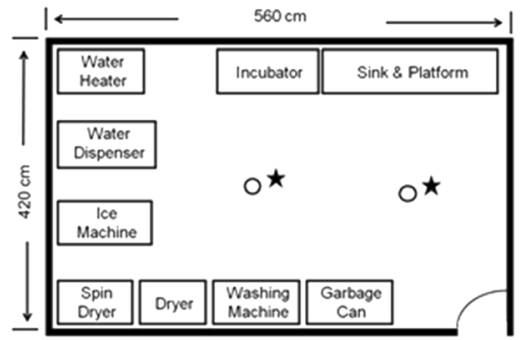

Fig. 1 Layouts of experimental area. a Overall layout of infectious disease ward containing twenty-seven negativepressure rooms, a nursing station, a soiled room and a dishwashing room. b Layout of soiled room with single

$\mathrm{ClO}_{2}$ and WAHW disinfection were then performed using two treatment protocols, namely a single (oneoff) application mode (SM) and a multiple (twicedaily) application mode (TM). The disinfection experiments were conducted during the summer months (July-September) of 2016 and winter months (January-February) of 2017. For each of the two experimental periods (winter and summer), $\mathrm{ClO}_{2}$ disinfection was performed for the first three weeks, while WAHW disinfection was performed for the last three weeks. For each experimental week, background air samples were collected on Monday, while background sampling, followed by SM disinfection/sampling was performed on Tuesday, and background sampling followed by TM disinfection/sampling was performed on Thursday. The detailed experimental methods are described in the following sections.

\subsection{Study area and sampling time}

Figure $1 \mathrm{~b}$ and $\mathrm{c}$ show the detailed floor plans of the SR and DR, respectively. According to the design blueprints, the two rooms had cubic volumes of $47 \mathrm{~m}^{3}$ and $57 \mathrm{~m}^{3}$, respectively. As shown in Fig. 1b, sampling and disinfection were performed at just one location within the SR. By contrast, sampling and disinfection were performed at two locations in the DR due to its larger size (see Fig. 1c). On each sampling day (Monday), background air samples were collected at 9:00 am and were then collected on an hourly basis until 4:00 pm. On each SM disinfection/sampling day (Tuesday), background air samples were collected at 9:00 am and disinfection/sampling was performed at 10:00 am. On each TM disinfection/sampling day sampling position $(\bigcirc)$ and application position $(\star)$. c Layout of dishwashing room with two sampling positions $(\bigcirc)$ and application positions $(\star)$

(Thursday), background air samples were collected at 9:00 am and disinfection/sampling was performed at $10.00 \mathrm{am}$ and 1:00 pm. The collected samples were analyzed to determine the concentrations of the various biological (bacteria and fungi) and nonbiological (suspended particle) components. In addition, an Aerocet-531 mass particle counter was applied for measuring the total number of suspended particles (TSP) (Met One Instruments, Inc., USA). Each sample was measured in triplicate for promising the reliability of the data. For studying the factors affecting the disinfection efficiencies of the two treatment protocols, the relative humidity and temperature in the SR and DR were detected with a humidity temperature (TES-1364, TES Corp., Taiwan). A Q-TRAK IAQ Meter (model 7565; TSI, Inc., USA) was used to detect the airflow velocity and $\mathrm{CO}_{2}$ concentration. The luminance was measured using a TES-1335 Digital Light Meter (TES Electrical Electronic Co., Taiwan). Afterward, the number of individuals in the room on each sampling occasion was counted and recorded.

\subsection{Disinfection methods}

By complying with the standard of the 8-h Time Weighted Average (TWA) for the maximum exposure limit for $\mathrm{ClO}_{2}$ of $0.3 \mathrm{mg} / \mathrm{m}^{3}$ (US OSHA 2006), disinfection was performed using $56.4 \mathrm{~mL}$ and $68.4 \mathrm{~mL}$ of $\mathrm{ClO}_{2}$ solution $(250 \mathrm{mg} / \mathrm{L})$ in the $\mathrm{SR}$ and $\mathrm{DR}$, respectively. There is no maximum exposure limit for WAHW. Therefore, the WAHW disinfection trials were applied using the same quantities in comparison with $\mathrm{ClO}_{2}$, which was performed using ultrasonic aerosol devices (Model EP606, Great Long 
Co., Ltd, Taiwan) placed at the locations shown in Fig. $1 \mathrm{~b}$ and $\mathrm{c}$. The average temperature in the two rooms exceeded $11{ }^{\circ} \mathrm{C}$ throughout the entire study period. Therefore, both disinfectants were evaporated instantly after nebulization and propagated by the local environment with the effects from the convection, natural ventilation and the air conditioning system.

The two disinfectants $\left(\mathrm{ClO}_{2}\right.$ and WAHW) were applied in both rooms (SR and DR). For convenience, the related treatments were annotated as $\mathrm{CSR}\left(\mathrm{ClO}_{2}\right.$ used in SR), CDR ( $\mathrm{ClO}_{2}$ used in DR), WSR (WAHW used in SR) and WDR (WAHW used in SR), respectively. Furthermore, for each disinfectant and both rooms, two different application modes were used, namely a single-daily disinfection mode (SM) and a twice-daily disinfection mode (TM). In the SM treatment mode, the disinfectant solutions were applied at 10:00 am and were not replenished as they nebulized. By contrast, in the TM treatment mode, the disinfectant solutions were applied at 10:00 am and were replenished after three hours (i.e., at 1:00 pm). For both application modes, the disinfection/sampling process was limited to a single day in each experimental week (i.e., Tuesday (SM) or Thursday (TM)).

\subsection{Air sample collection}

On each sampling day or disinfection/sampling day, air samples were collected as described previously in order to determine the concentrations of bacteria and fungi, respectively. For these disinfectants, samples were collected from the single sampling location shown in Fig. 1b for the SR and two sampling locations shown in Fig. 1c for the DR. In every case, a volume of $1000 \mathrm{~L}$ was sampled based on the related Taiwan NIEA (2016) guidelines (i.e., NIEA E301.15C for bacteria and NIEA E401.15C for fungus). Particularly, a MAS-100 Eco Microbial Air Sampler (Merck, Germany, $100 \mathrm{~L} / \mathrm{min}$ ) containing petri dishes with Tryptic Soy Agar (TSA, Merck) plates and Malt Extract Agar (MEA, Merck) plates was used to collect samples. After 10-min of collection period, the petri dishes were removed from the sampler for cultivating the bioaerosols. The TSA plates after collection were then incubated at $30 \pm 1{ }^{\circ} \mathrm{C}$ for $48 \pm 2 \mathrm{~h}$. The MEA plates for the fungus bioaerosols were incubated at $25 \pm 1{ }^{\circ} \mathrm{C}$ for $4 \pm 1$ days. The concentrations of bacteria and fungi concentrations were then determined with the colonies on the respective agar surfaces using a Galaxy 230 colony counter meter (Rocker Co., Taiwan).

\subsection{Statistical analysis}

The experimental data were analyzed with a commercial SPSS software (SPSS 2003; Version 12.0). The effects of the environmental factors (i.e., the temperature, relative humidity, airflow velocity, $\mathrm{CO}_{2}$ level, luminance and TSP concentration) on the bacteria and fungi levels were statistically compared using a multivariate analysis of variance technique (MANOVA, $p<0.05)$. In addition, the mean difference between the effects of the two disinfection modes on the bacteria and fungus colony counts in the winter and summer periods, respectively, was evaluated using Duncan's multiple-range test $(p<0.05$; SPSS Inc., USA 2003). The effectiveness of the two disinfection agents $\left(\mathrm{ClO}_{2}\right.$ and WAHW) with the two different treatment modes were evaluated by means of t-tests. For each mode, the differences in the colony counts after $\mathrm{ClO}_{2}$ and WAHW disinfection were evaluated by a nonparametric Friedman analysis test $(p<0.05)$. Finally, the correlations between the colony counts and the environmental parameters were evaluated by Pearson's correlation analysis $(p<0.05)$.

\section{Results and discussion}

Prior to the main experimental stage of the study, preliminary measurements were made of the IAQ of the negative-pressure rooms in the infectious disease ward (see Fig 1a). The average bacteria concentration was found to be less than $1500 \mathrm{CFU} / \mathrm{m}^{3}$, while the average fungi concentration was less than $1000 \mathrm{CFU} /$ $\mathrm{m}^{3}$. In other words, the air quality was consistent with the requirements of the TEPA Indoor Air Quality act (Taiwan EPA 2012) in Taiwan. This finding is reasonable since the negative-pressure rooms are private and closed spaces, in which thorough microbial control is performed every day by means of surface disinfection using $0.1 \%$ bleach. In view of this finding, the negative-pressure rooms were excluded from the study, and the remaining experiments were conducted only in the public soiled room (SR) and dishwashing room (DR) of the ward. 
Table 1 shows the measured values of the environmental parameters in the SR and DR during the two study periods (winter and summer). Results were presented before and after disinfection, respectively. It was observed that for each study period and both study rooms ( $\mathrm{SR}$ and $\mathrm{DR}$ ), there is no obvious difference between the measured values of the environmental factors before and after disinfection. However, with increasing the number of individuals presence, the luminance and the TSP in the DR were higher than those in the SR since the DR contained a greater number of functions and activities than the SR, leading tomore individuals entering and leaving the room.

By Sect. 2.1, it can be found the reason that people number changed. On each sampling day (Monday), background air samples were collected at 9:00 am and were then collected on an hourly basis until 4:00 pm. On each SM disinfection/sampling day (Tuesday), background air samples were collected at 9:00 am and disinfection/sampling was performed at 10:00 am. On each TM disinfection/sampling day (Thursday), background air samples were collected at 9:00 am and disinfection/sampling was performed at $10.00 \mathrm{am}$ and 1:00 pm.

Before disinfection, the number of individuals' presence is the one, which people entered and left on Monday from 9 am to $4 \mathrm{pm}$ and Tuesday and Thursday at $9 \mathrm{am}$. After disinfection, the number of people entering and leaving on Tuesday and Thursday from 10 am to $4 \mathrm{pm}$, and therefore this has been changed.

In addition, the temperature, relative humidity and luminance in the summer period were higher than those in the winter time in both rooms due to the characteristic hot, bright and humid conditions summer.

Table 2 shows the Pearson's correlation analysis results for the effects of the environmental factors on the bacteria and fungi colony counts prior to disinfection. It is seen that significant positive correlations existed between the bacteria concentration and the indoor temperature $(r=0.397, p<0.01)$ as welll as luminance $(r=0.150, p<0.05)$. Moreover, significant positive correlations also existed between the fungi concentration and the indoor temperature $(r=0.156, p<0.05)$. In other words, the bacteria concentration increased with an increasing temperature and luminance, while the fungi concentration increased with an increasing temperature.
Consequently, the results presented in Tables 1 and 2 reveal that the bacteria and fungi concentrations increased in the summer period.

Figures 2 and 3 show the MANOVA and Duncan test analysis results for the effects of the different application conditions (CSR, CDR, WSR and WDR) on the residual bacteria and fungi colonies, respectively, in the winter and summer periods. For each application condition, significant differences $(p<0.05)$ in the residual concentration level following disinfection are annotated with different letters (ac).

The results presented in Fig. 2 confirm that the bacteria concentration increased in the summer. During the winter period, there was no significant difference between the background bacteria concentration level and the post-disinfection concentration level, irrespective of the disinfection mode employed. However, the results show that the bacteria concentration levels (both before disinfection and after disinfection) were comfortably lower than the maximum limit of $1500 \mathrm{CFU} / \mathrm{m}^{3}$ prescribed in the TEPA standard (Taiwan EPA 2016). In the summer period, the background value of the bacteria concentration in the DR was higher than that in the SR and exceeded the maximum limit of $1500 \mathrm{CFU} / \mathrm{m}^{3}$. For all four application conditions (CSR, CDR, WSR and WDR), both treatment modes (SM and TM) resulted in a significant reduction in the number of bacteria colonies. In other words, both treatment modes provided a good disinfection effect. Irrespective of the disinfectant applied, or the treatment mode employed, the residual bacteria count following disinfection was lower than the maximum value of $1500 \mathrm{CFU} / \mathrm{m}^{3}$ prescribed in the TEPA standard (Taiwan EPA 2016). However, for both treatment modes (SM and TM), the disinfection efficiency of $\mathrm{ClO}_{2}$ was significantly better than that of WAHW in both rooms. Furthermore, for each disinfectant, and both rooms, the TM treatment mode resulted in a lower residual bacteria concentration than the SM treatment mode.

Figure 3 shows the residual fungi colonies in the SR and DR during the winter and summer periods for each of the four disinfection conditions (i.e., CSR, CDR, WSR and WDR) and both treatment modes (SM and TM). During winter time, the background fungi concentration level was very low, and hence both disinfectants $\left(\mathrm{ClO}_{2}\right.$ and WAHW $)$ has a significant 


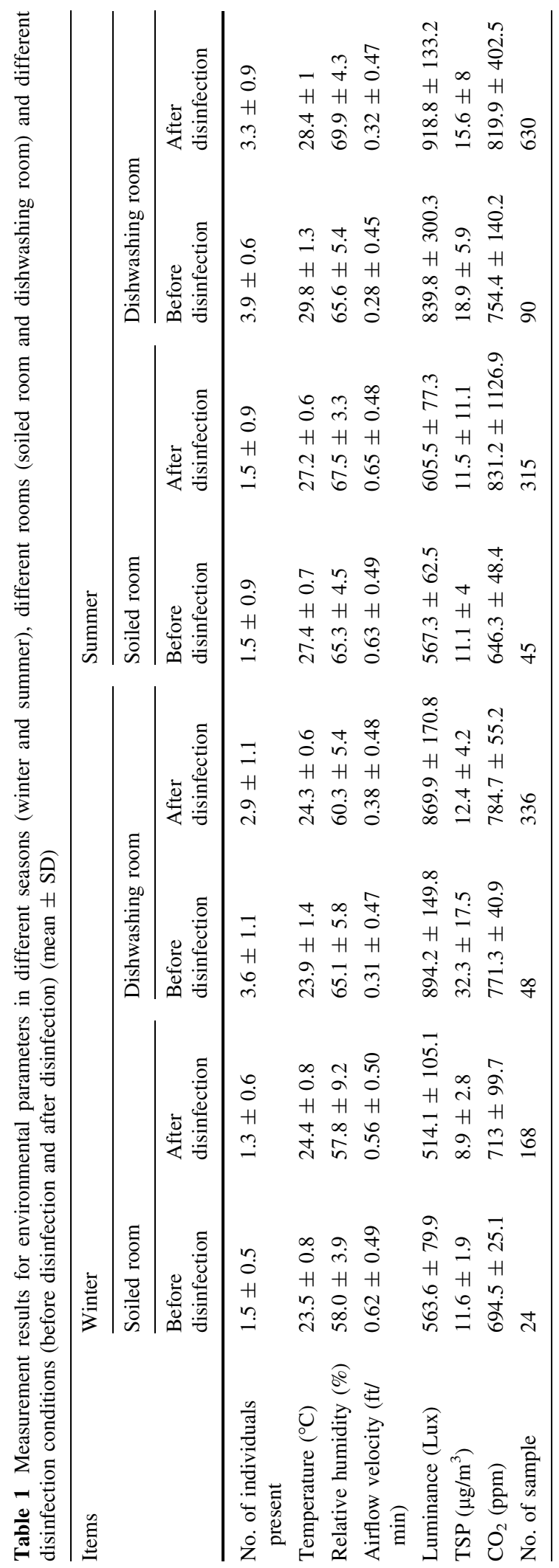


Table 2 Correlations between bioaerosol concentrations and environmental parameters obtained via Pearson's correlation analysis $(N=246)$. Note that parameters were measured before disinfection

\begin{tabular}{llllllll}
\hline Items & $\begin{array}{l}\text { Bacteria } \\
\text { concentration }\end{array}$ & $\begin{array}{l}\text { Fungi } \\
\text { concentration }\end{array}$ & $\begin{array}{l}\text { No. of } \\
\text { individuals } \\
\text { present }\end{array}$ & Temperature & $\begin{array}{l}\text { Relative } \\
\text { humidity }\end{array}$ & $\begin{array}{l}\text { Airflow } \\
\text { velocity }\end{array}$ & $\begin{array}{l}\text { Carbon } \\
\text { dioxide }\end{array}$ \\
\hline
\end{tabular}

\begin{tabular}{|c|c|c|c|c|c|c|c|c|}
\hline $\begin{array}{l}\text { Fungi } \\
\text { concentration }\end{array}$ & .078 & & & & & & & \\
\hline $\begin{array}{l}\text { No. of } \\
\text { individuals } \\
\text { present }\end{array}$ & -.091 & -.105 & & & & & & \\
\hline Temperature & $.397 * *$ & $.156^{*}$ & $-.338^{*}$ & & & & & \\
\hline $\begin{array}{l}\text { Relative } \\
\text { humidity }\end{array}$ & .056 & -.090 & $.177 * *$ & -.079 & & & & \\
\hline Airflow velocity & .028 & .073 & $.418^{*}$ & $-.289 * *$ & .090 & & & \\
\hline Carbon dioxide & -.110 & -.008 & $.542 * *$ & $-.279 * *$ & .155 & .019 & & \\
\hline TSP & -.007 & -.110 & $.138^{*}$ & $-.176^{* *}$ & -.046 & -.009 & $.208 *$ & \\
\hline Luminance & $.150 *$ & .074 & $-.392 * *$ & $.396 * *$ & -.007 & $-.293 * *$ & -.227 & $.265^{* *}$ \\
\hline
\end{tabular}

*Correlation is significant at the 0.05 level (2-tailed)

${ }^{* *}$ Correlation is significant at the 0.01 level (2-tailed)

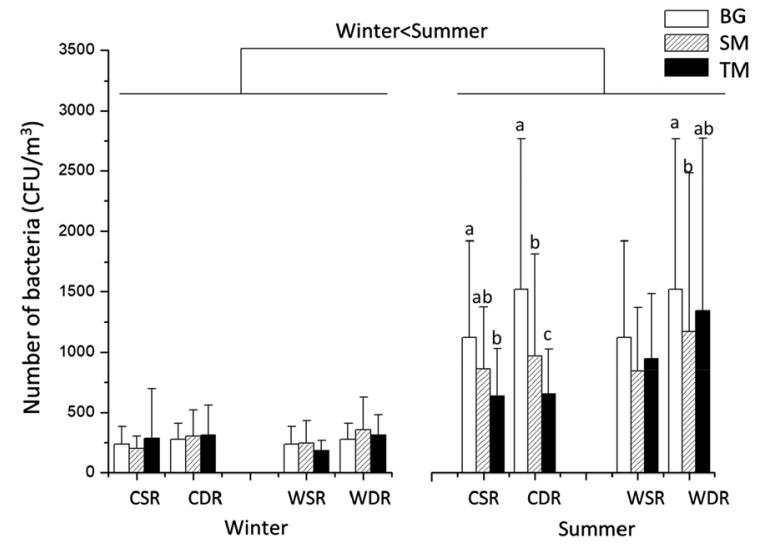

Fig. 2 Background level (BG) bacteria colonies and residual bacteria colonies in winter and summer periods for two application modes (SM and TM), two disinfectants $\left(\mathrm{ClO}_{2}\right.$ and WAHW) and two application rooms (SR and DR). Note that for each disinfection combination (CSR, CDR, WSR and WDR), significant differences $(p<0.05)$ among $\mathrm{BG}, \mathrm{SM}$ and TM are annotated with different letters (a-c) according to MANOVA and Duncan's tests. Note also that the bars represent the mean $\pm \mathrm{SD}$. CSR $\left(\mathrm{ClO}_{2}\right.$ used in $\left.\mathrm{SR}\right), \mathrm{CDR}\left(\mathrm{ClO}_{2}\right.$ used in DR), WSR (WAHW used in SR) and WDR (WAHW used in SR)

disinfection effect. Furthermore, no significant difference was observed in the disinfection efficiencies of the two treatment modes (i.e., SM and TM). In the summer months, the residual fungi concentration levels in the two rooms were higher than those in the

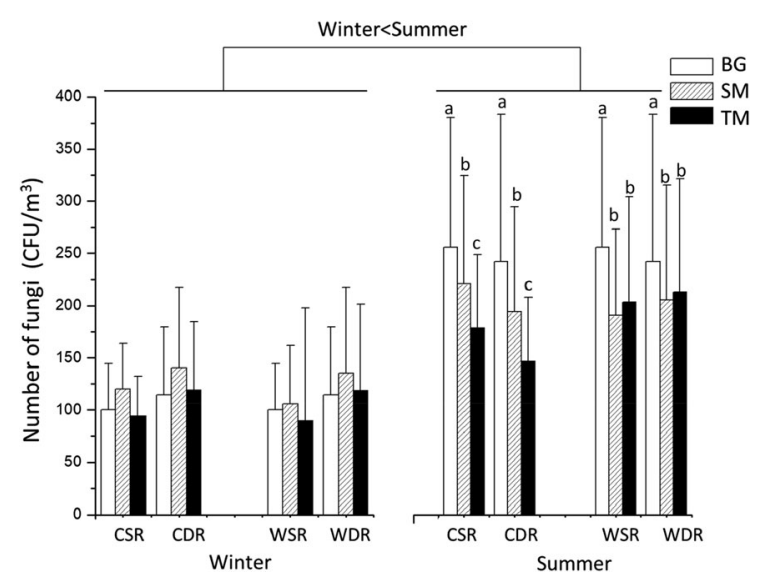

Fig. 3 Background level (BG) fungus colonies and residual fungus colonies in winter and summer periods for two application modes (SM and TM), two disinfectants $\left(\mathrm{ClO}_{2}\right.$ and WAHW) and two application rooms (SR and DR). Note that for each disinfection combination (CSR, CDR, WSR and WDR), significant differences $(p<0.05)$ among BG, SM and TM are annotated with different letters $(\mathbf{a}-\mathbf{c})$ according to MANOVA and Duncan's tests. Note also that the bars represent the mean $\pm \mathrm{SD}$. CSR $\left(\mathrm{ClO}_{2}\right.$ used in $\left.\mathrm{SR}\right), \mathrm{CDR}\left(\mathrm{ClO}_{2}\right.$ used in $\left.\mathrm{DR}\right)$, WSR (WAHW used in SR) and WDR (WAHW used in SR)

winter. However, they were still well below the TEPA recommended value of $1000 \mathrm{CFU} / \mathrm{m}^{3}$ (Taiwan EPA 2012). When using $\mathrm{ClO}_{2}$ as the disinfectant, the TM treatment mode provided a more obvious disinfection effect than the SM mode. However, when using 
WAHW as the disinfectant, no obvious difference in the disinfection efficiencies of the two treatment modes was observed.

The whole results in Figs. 2 and 3 show that both disinfectants $\left(\mathrm{ClO}_{2}\right.$ and WAHW) at both disinfection modes (SM and TM) had good disinfection efficiencies in these two rooms (SR and DR). Table 3 presents the Pearson's correlation analysis for the environmental factors affecting the bacteria and fungus colony counts after disinfection. Results show that the correlations are positive between the residual bacteria concentration and the residual fungi concentration ( $r=0.154, p<0.01)$, the number of individuals presented $(r=0.167, p<0.01)$, the indoor relative humidity $(r=0.195, p<0.01)$, the TSP concentration $(r=0.181, p<0.01)$ and the luminance $(r=0.073$, $p<0.01)$. Significant positive correlations also occurred between the residual fungi concentration and the TSP concentration $(r=0.064, p<0.05)$ as well as luminance $(r=0.064, p<0.05)$. However, the correlations were significantly negative between the residual bacteria concentration and the airflow velocity $(r=-0.066, p<0.05)$ and between the residual fungi concentration and the relative humidity ( $r=-0.245, p<0.01)$. Consequently, the residual bacteria concentration increased with increasing residual fungi concentration, number of individuals present, indoor relative humidity, TSP concentration and luminance. However, it decreased with increasing airflow velocity. A similar results can be found that the residual fungi concentration increased with increasing TSP concentration and luminance, but decreased with increasing humidity. This result does not mean that the fungal concentration affected the bacterial concentration. However, the number of people present will affect the results of disinfection, resulting in a positive deviation from the amount of residual bacteria.

Figures 2 and 3 show that both disinfectants provided a high-disinfection efficiency in the two rooms. Due to the negative correlation between the airflow velocity and the residual bacteria concentration, it was found that the rapid mixing of air within the indoor space could enhance the distribution of the evaporated disinfectants, leading to the improvement of the disinfection efficiency. After disinfection, the bacteria and fungi concentrations were positively correlated with the TSP concentration and luminance (Table 3). Based on the results, it can be found that both factors reduced the efficiency of the disinfection process because $\mathrm{ClO}_{2}$ and WAHW can be decomposed by light illumination (Obvintseva and Gubanova 2004; Vogt et al. 2011; Feng et al. 2007). Furthermore, the bacteria and fungi concentration levels inevitably increased with an increase in TSP

Table 3 Correlations between bioaerosol concentrations and environmental parameters obtained via Pearson's correlation analysis $(N=1449)$. Note that parameters were measured after disinfection

\begin{tabular}{|c|c|c|c|c|c|c|c|c|}
\hline Items & $\begin{array}{l}\text { Bacteria } \\
\text { concentration }\end{array}$ & $\begin{array}{l}\text { Fungi } \\
\text { concentration }\end{array}$ & $\begin{array}{l}\text { No. of } \\
\text { individuals } \\
\text { present }\end{array}$ & Temperature & $\begin{array}{l}\text { Relative } \\
\text { humidity }\end{array}$ & $\begin{array}{l}\text { Airflow } \\
\text { velocity }\end{array}$ & $\begin{array}{l}\text { Carbon } \\
\text { dioxide }\end{array}$ & TSP \\
\hline $\begin{array}{l}\text { Fungi } \\
\text { concentration }\end{array}$ & $.154 * *$ & & & & & & & \\
\hline $\begin{array}{l}\text { No. of } \\
\text { individuals } \\
\text { present }\end{array}$ & $.167 * *$ & -.012 & & & & & & \\
\hline Temperature & .046 & -.018 & -.004 & & & & & \\
\hline $\begin{array}{l}\text { Relative } \\
\text { humidity }\end{array}$ & $.195 * *$ & $-.245^{* *}$ & $.243 * *$ & $.091 * *$ & & & & \\
\hline Airflow velocity & $-.066^{*}$ & .050 & $-.214^{* *}$ & .024 & -.016 & & & \\
\hline Carbon dioxide & .011 & .008 & -.004 & .007 & $.072 * *$ & $.065^{*}$ & & \\
\hline TSP & $.181 * *$ & $.064 *$ & $.401 * *$ & .029 & $.148 * *$ & $-.103^{* *}$ & -.026 & \\
\hline Luminance & $.073 * *$ & $.064 *$ & $.425 * *$ & .023 & $.158 *$ & $-.213 * *$ & .022 & $.183 * *$ \\
\hline
\end{tabular}

*Correlation is significant at the 0.05 level (2-tailed)

${ }^{* * *}$ Correlation is significant at the 0.01 level (2-tailed) 
because the TSP count included bioaerosols regardless of the disinfection process applied.

In addition, Lin et al. (2007) studied on the disinfection efficiency by using chlorine dioxide for the closed out-patient area of the physician department in the hospital and found that after $30 \mathrm{~min}$, the average colony number in the physician out-patient area decreased from 421 to $21 \mathrm{CFU} / \mathrm{m}^{3}$ with a disinfection efficiency of $95.0 \%$. However, in the present study, the disinfection efficiencies were only in the range of 16.6-50\%. By comparing these two studies, it was found that the efficiencies were very different because in the present study, the space was not closed during the disinfection and people can come in and out freely. However, it still can prove that chlorine dioxide can enhance the air quality in the hospital.

Chlorine dioxide can also be efficiently applied for other sites. Lu et al. (2018a) concluded that chlorine dioxide can improve the indoor air quality of the university library and the faster air velocity was beneficial in spreading the disinfectants through the indoor space and improving the disinfection performance. Lu et al. (2018b) presented that gaseous chlorine dioxide disinfection improved the air quality in the pet shop interior, and thus beneficial in safeguarding the health of the pet shop staff and visitors. Furthermore, chloride dioxide can be applied for the operation of hospital wastes and wastewater disinfection during COVID-19 pandemic in China (Wang et al. 2020).

\section{Conclusions}

In winter, the bacteria and fungi concentrations in the SR and DR were both relatively low, and hence no significant difference was found between the residual bacterium and fungal colonies before and after disinfection regardless of the disinfection method employed. The residual bacteria and fungi concentrations before disinfection in the summer are higher than those in the winter. For both application modes (SM and TM), the bacteria disinfection efficiency of $\mathrm{ClO}_{2}$ was better than that of WAHW in both rooms. When using $\mathrm{ClO}_{2}$ as the disinfectant, the disinfection efficiency of the TM treatment mode was better than that of the SM treatment mode. However, when using WAHW as the disinfectant, no significant difference was found between the disinfection efficiencies of the two methods. Consequently, the results suggest that among the various disinfection protocols, twice daily disinfection with $\mathrm{ClO}_{2}$ has the highest efficiency and can satisfy the Taiwan EPA guidelines for the IAQ in hospital infectious disease wards.

Acknowledgements The authors would like to thank the Ministry of Science and Technology, Taiwan, for the financial support of this study under Contract No.105-2815-C-041-003-E.

\section{References}

Abadias, M., Usall, J., Oliveira, M., Alegre, I., \& Vinas, I. (2008). Efficacy of neutral electrolyzed water (NEW) for reducing microbial contamination on minimally processed vegetables. International Journal of Food Microbiology, 123(1-2), 151-158.

Abreu, A. C., Tavares, R. R., Borgaes, A., Mergulhão, F., \& Simões, M. (2013). Current and emergent strategies for disinfection of hospital environments. Journal of Antimicrobial Chemotherapy, 68, 2718-2732.

AIHA. (1996). Field guide for the determination of biological contaminants in environmental samples. Fairfax, Va.: AIHA Press.

ACGIH. (1989). Guidelines for assessment of bioaerosols in the indoor environment. Cincinnati, Ohio, American Conference of Governmental Industrial Hygienists.

ACGIH. (1999). Bioaerosols: Assessment and control (1st ed.) Cincinnati, OH, American Conference of Governmental Industrial Hygienists.

Beggs, C. B. (2003). The airborne transmission of infection in hospital buildings: fact or fiction? Indoor and Built Environment, 12(4), 9-18.

Bhalla, A., Pultz, N. J., Gries, D. M., Ray, A. J., Eckstein, E. C., Aron, D. C., \& Donskey, C. J. (2004). Acquisition of nosocomial pathogens on hands after contact with environmental surfaces near hospitalized patients. Infection Control and Hospital Epidemiology, 25(2), 164-167.

Boyce, J. M. (2007). Environmental contamination makes an important contribution to hospital infection. Journal of Hospital Infection, 65(S2), 50-54.

Buttner, M. P., Cruz, P., Stetzenbach, L. D., Klima-Comba, A. K., Stevens, V. L., \& Cronin, T. D. (2004). Determination of the efficacy of two building decontamination strategies by surface sampling with culture and quantitative PCR analysis. Applied and Environment Microbiology, 70, 4740-4747.

Cao, W., Zhang, C., \& Li, B. (2012). Effect of spraying subacidic electrolyzed water on buckwheat sprouts growth. Transactions of the Chinese Society of Agricultural Engineering, 28(9), 159-164.

Chuang, C. Y., Yang, S., Chang, M. Y., Huang, H. C., Luo, C. H., Hung, P. C., \& Fang, W. (2013). Inactivation efficiency to Bacillus subtilis and Escherichia coli bacterial aerosols of spraying neutral electrolyzed water. Journal of the Air and Waste Management Association, 63(12), 1447-1456. 
Dancer, S. J. (2009). The role of environmental cleaning in the control of hospital-acquired infection. Journal of Hospital Infection, 73, 378-385.

Feng, Y., Smith, D. W., \& Bolton, J. R. (2007). Photolysis of aqueous free chlorine species $\left(\mathrm{HOCl}\right.$ and $\left.\mathrm{OCl}^{-}\right)$with $254 \mathrm{~nm}$ ultraviolet light. Journal of Environmental Engineering and Science, 6, 277-284.

Hricova, D., Stephan, R., \& Zweifel, C. (2008). Electrolyzed water and its application in the food industry. Journal of Food Protection, 71(9), 1934-1947.

Hsu, C. S., Lu, M. C., \& Huang, D. J. (2012). Application of chlorine dioxide for disinfection of student health centers. Environmental Monitoring and Assessment, 184, 741-747.

Hsu, C. S., Lu, M. C., \& Huang, D. J. (2015). Disinfection of indoor air microorganisms in stack room of university library using gaseous chlorine dioxide. Environmental Monitoring and Assessment, 187, 2-11.

Issa-Zacharia, A., Kamitani, Y., Morita, K., \& Iwasaki, K. (2010). Sanitization potency of slightly acidic electrolyzed water against pure cultures of escherichia coli and staphylococcus aureus, in comparison with that of other food sanitizers. Food Control, 21(5), 740-745.

Kim, H. J., Lee, J. G., Kang, J. W., Cho, H. J., Kim, H. S., Byeon, H. K., \& Yoon, J. H. (2008). Effects of a low concentration hypochlorous acid nasal irrigation solution on bacteria, fungi, and virus. Laryngoscope, 118(10), 1862-1867.

Koide, S., Takeda, J., Shi, J., Shono, H., \& Atungulu, G. G. (2009). Disinfection efficacy of slightly acidic electrolyzed water on fresh cut cabbage. Food Control, 20(3), 294-297.

Lin, K. S., Hsieh, M. J., Liou, M. J., Lee, S. L., \& Lai, C. K. (2007). Disinfection effect of chlorine dioxide on air quality control in armed forces general hospital of Taiwan. Nature and Science, 5(4), 94-99.

Loret, J. F., Robert, S., Thomas, V., Cooper, A. J., McCoy, W. F., \& Levi, Y. (2005). Comparison of disinfectants for biofilm, protozoa and Legionella control. Journal of Water and Health, 3, 423-433.

Lowe, J. J., Gibbs, S. G., Iwen, P. C., Smith, P. W., \& Hewlett, A. L. (2013). Impact of chlorine dioxide gas sterilization on nosocomial organism viability in a hospital room. International Journal of Environmental Research and Public Health, 10(6), 2596-2605.

Lu, M.-C., Hsu, C.-S., Huang, D.-J., Liang, C.-K., \& Chen, G.M. (2018). Improvement of indoor air quality in pet shop using gaseous chlorine dioxide. Environmental Monitoring and Assessment, 190, 371-379.

Lu, M.-C., Hsu, C.-S., Huang, D.-J., Liang, C.-K., \& Huang, J.W. (2018). Statistical evaluation of disinfection performance of chlorine dioxide and WAHW in improving indoor air quality of university library. Journal of Aerosol Science, 115, 113-120.

Maclean, M., McKenzie, K., Moorhead, S., Tomb, R. M., Coia, J. E., MacGregor, S. J., \& Anderson, J. G. (2015). Decontamination of the hospital environment: New technologies for infection control. Current Treatment Options in Infectious Diseases, 7, 39-51.

Møretrø, T., Heir, E., Nesse, L. L., Vestby, L. K., \& Langsrud, S. (2012). Control of salmonella in food related environments by chemical disinfection. Food Research International, 45(2), 532-544.

NIOSH (1998). Sampling and characterization of bioaerosols. In Schlecht PC, O'Connor PF (Eds.), NIOSH manual of analytical methods. Cincinnati, OH. US Department of Health and Human Services, National Institute for Occupational Safety and Health.

Obvintseva, L. A., \& Gubanova, D. P. (2004). Rapid detection of chlorine and chlorine dioxide in air using semiconductor sensors. Journal of analytical chemistry, 59(8), 785-787.

Ogata, N., Sakasegawa, M., Miura, T., Shibata, T., Takigawa, Y., Taura, K., et al. (2016). Inactivation of airborne bacteria and viruses using extremely low concentrations of chlorine dioxide gas. Pharmacology, 97, 301-306.

Ono, T., Yamashita, K., Murayama, T., \& Sato, T. (2012). Microbicidal effect of weak acid hypochlorous solution on various microorganisms. Biocontrol Science, 17, 129-133.

Quan, Y., Choi, K. D., Chung, D., \& Shin, I. S. (2010). Evaluation of bactericidal activity of weakly acidic electrolyzed water (WAEW) against vibrio vulnificus and Vibrio parahaemolyticus. International Journal of Food Microbiology, 136(3), 255-260.

Rahman, S. M. E., Ding, T., \& Oh, D. H. (2010). Inactivation effect of newly developed low concentration electrolyzed water and other sanitizers against microorganisms on spinach. Food Control, 21(10), 1383-1387.

Taiwan EPA (2012). Guidelines on indoor air quality, Taiwan environmental protection administration, Retrieved Dec 5, 2012, from https://www.indoorair.org.tw/.

Taiwan EPA. (2016). The compilation of detection methods on air quality. Taipei, Taiwan: Environmental Analysis Laboratory EPA. ((in Chinese)).

Tang, C. S., \& Wan, G. H. (2013). Air quality monitoring of the post-operative recovery room and locations surrounding operating theaters in a medical center in Taiwan. PLoS ONE, 8(4), e61093.

US EPA. (2007). Pesticides: Topical and chemical fact sheetschlorine dioxide. Washington, DC: United States Environmental Protection Agency.

US OSHA. (2006). Occupational safety and health guideline for chlorine dioxide. Retrieved Jul 7, 2018, from https://www. osha.gov/SLTC/healthguidelines/chlorinedioxide/ recognetion.html.

Vogt, H., Balej, J., Bennett, J. E., Wintzer, P., Sheikh, S. A., Gallone, P., et al. (2011). Chlorine oxides and chlorine oxygen acids. In Wiley-VCH (Ed.), Ullmann's encyclopedia of industrial chemistry (7th ed.). New York: Wiley$\mathrm{VCH}$.

Wang, J., Shen, J., Ye, D., Yan, X., Zhang, Y., Yang, W., et al. (2020). Disinfection technology of hospital wastes and wastewater: Suggestions for disinfection strategy during coronavirus disease 2019 (COVID-19) pandemic in China. Environmental Pollution, 262, 114665.

Zhang, C., Lu, Z., Li, Y., Shang, Y., Zhang, G., \& Cao, W. (2011). Reduction of escherichia coli O157:H7and salmonella enteritidis on mung bean seeds and sprouts by slightly acidic electrolyzed water. Food Control, 22(5), 792-796. 